\title{
Resistance to witches' broom in adult plants and progeny of local varieties of cacao in Southern Bahia
}

\author{
Alice Lichs Marssaro ${ }^{1}$, Alberto Montejo-Díaz² (D), Victor Miguel Montaño-Orellana² (iD), Edna Dora \\ Martins Newman Luz ${ }^{3}$ (D), Ronan Xavier Corrêa ${ }^{4 *}$ (D) \\ 1. Universidade Estadual de Santa Cruz - Programa de Pós-Graduação em Produção Vegetal - Ilhéus (BA), Brazil. \\ 2. Universidade Estadual de Santa Cruz - Programa de Pós-Graduação em Genética e Biologia Molecular - Ilhéus (BA), Brazil. \\ 3. Centro de Pesquisas do Cacau - Comissão Executiva do Plano da Lavoura Cacaueira - Ilhéus (BA), Brazil. \\ 4. Universidade Estadual de Santa Cruz - Departamento de Ciências Biológicas - Ilhéus (BA), Brazil.
}

\begin{abstract}
Plants of local cacao variety from Southern Bahia were evaluated in order to verify if there are different levels of resistance to witches' broom disease in the study population and if the evaluation of adult plants in the field is a good predictor of these resistance levels. The seedlings were maintained under greenhouse conditions and inoculated with the fungus Moniliophthora perniciosa. Evaluations of symptoms occurred 60 days after inoculation. In the field, the same genotypes were evaluated by counting the number of dry brooms per plant, per year, and assessing trunk diameter size. The data were subjected to analysis of variance and averages grouped by the Scott-Knott test, differentiated by Tukey's test and compared by Student's T test. The Scavina- 6 and CCN51 clones as well as the Catongo variety were used as resistance, moderate resistance and susceptibility patterns, respectively. Twenty-eight percent of the genotypes were among the most resistant and the genotypes 4119 and 4033 were considered the most susceptible to the disease in both field and greenhouse evaluations. Field evaluation was promising as a predictor of resistance level. The selected materials presented good characteristics for witches' broom resistance, with different levels deserving special attention in the context of reducing the vulnerability of Brazilian cacao cultivation to the effects of the disease, especially in the cacao region of Bahia.
\end{abstract}

Key words: Moniliophthora perniciosa, disease resistance, Theobroma cacao, traditional variety.

\author{
Received: \\ Jul. 28, 2020 \\ Accepted: \\ Aug. 26, 2020 \\ Section Editor: \\ Gabriel Constantino Blain \\ ${ }^{*}$ Corresponding author: \\ ronanxc@uesc.br
}

\section{INTRODUCTION}

Brazil is the seventh largest producer of cacao in the world, having produced around 250,925 tons of cacao beans in the 2019 harvest in a planted area of approximately 578,122 hectares. About $48 \%$ of this production takes place in Bahia, the second largest national producer (IBGE 2019).

Among the diseases that affect cacao culture, witches' broom, caused by the fungus Moniliophthora (Sin: Crinipellis) perniciosa (Stahel) is considered, in Brazil, the most devastating (Ploetz 2016). Most of the resistant clones and varieties cultivated in Bahia are descended from the Scavina-6 clone (Pinto and Pires 1998). However, varieties derived from this clone have been reported with symptoms of the disease (Faleiro et al. 2004). Moreover, resistance to witches' broom in local cacao varieties is an object of concern, given the growing niche of fine chocolate market which appreciates the flavor and historical characteristics of beans in these varieties.

Studies have shown that there is variability in the sources of resistance to witches' broom that are distinguished from the descendants of Scavina- 6 and that have good agronomic characteristics in genetic materials selected on local farms 
(Leal et al. 2008; Lima et al. 2013; Santos et al. 2015). However, few resistant plants have been selected so far and there is a shortage of genetic information about them.

The fine chocolate niche market has grown substantially around the world (Leite 2018), and Brazil has recently been officially recognized by the International Cocoa Organization (ICCO) as a fine cocoa exporting country (Brazil 2019). The origin and quality of cocoa beans along with postharvest factors are critical to achieving excellence chocolate (Afoakwa et al. 2008). Beans from cocoa varieties in Southern Bahia have been internationally recognized for the quality of their sensory characteristics and consequent potential for producing fine or gourmet chocolate.

Studies of identification and selection of new sources of resistance to witches' broom involve steps developed in a greenhouse and/or field (Benjamin et al. 2016; Pimenta Neto et al. 2018). The methodologies are equally important and complementary (not exclusive); however, they may require excessive time and resources when performed together. Field evaluations rely on the natural conditions of infection and disease manifestation and the possibility of expression of the biotic and abiotic interactions inherent to the pathosystem. Thus, the practice can be seen as a good predictor of the resistance level and, being practiced by the producer themselves on their property, results in optimization of resources and time.

Given the above, it is important to increase the genetic diversity of local varieties of cacao plants in Southern Bahia, preventing the eventual evolution of the pathogen and finally contributing to the durability of resistance in these varieties. Therefore, the objectives of this study were to assess whether (i) there are different levels of resistance to witches' broom disease in the study population and (ii) the field evaluation can be seen as a good predictor of resistance levels to this disease.

\section{MATERIAL AND METHODS}

\section{Plant material}

The plant material consisted of 96 genotypes of traditional local cacao varieties from Bahia cultivated in the "cacaucabruca" agroforestry ecological system in the municipality of Uruçuca, Bahia. Scavina-6 (SCA6) and CCN51 (Colección Castro Naranjal) clones, and the Catongo variety were used as patterns of resistance, moderate resistance and susceptibility to witches' broom, respectively.

\section{Evaluation of symptoms}

The resistance evaluation tests occurred in a greenhouse by artificial inoculation and in the field by natural infection. In the greenhouse, open-pollinated seeds were planted in $288 \mathrm{~cm}^{3}$ plastic tubes containing a mixture of sterile soil and plant substrate composed of pine bark, coconut fiber and expanded vermiculite in a 1:1 ratio. The seedlings received the recommended cacao crop treatments, with daily irrigation and pest and disease control. Each seedling was identified in accordance with the field matrix that gave rise to it. Due to heterogeneous fructification and the laboratory limitation on the number of samples to be processed per day, the materials were divided into 12 batches with presence of the three patterns in all of them.

Thirty days after planting, the seedlings were artificially inoculated with suspension of basidiospores of the fungus M. perniciosa. The basidiospores were obtained according to the methodology described by Dickstein et al. (1987) and subjected to a viability test proposed by Frias et al. (1995). The inoculation process was performed according to a previously established methodology, in which $30 \mu \mathrm{L}$ of the inoculum with concentration adjusted to $2 \times 10^{5}$ basidiospores $\cdot \mathrm{mL}^{-1}$ was deposited in $0.2 \%$ agar-water medium in the apical bud (Pimenta Neto et al. 2018).

Sixty days after inoculation, each plant was assessed for the number and type of broom. For data analysis, the disease index (DI) proposed by Rodrigues et al. (2019) was calculated following the model (Eq. 1): 


$$
\mathrm{DI}=\mathrm{TB}+\mathrm{AB}+\mathrm{CB}+\left(4.3^{\star} \mathrm{DB}\right)+\left(0.1^{\star} \mathrm{LTB}\right)+\left(0.2^{\star} \mathrm{NAB}\right)
$$

Where: $\mathrm{TB}=$ presence of terminal broom; $\mathrm{AB}=$ presence of axillary broom; $\mathrm{CB}=$ presence of cotyledon broom; $\mathrm{DB}=$ presence of dry broom; LTB = length of terminal broom; NAB = number of axillary brooms $>1 \mathrm{~cm}$.

In the field, the same genotypes were evaluated for the number of dry brooms (DB) per plant, per year, and the size of trunk diameter, measured at $50 \mathrm{~cm}$ from the base of the plant, during the periods of July 2018 and July 2019.

\section{Statistical analysis}

A randomized block design (RBD) was used for the data from the field evaluations (DB and trunk diameter). The data were subjected to F-test of analysis of variance and averages grouped by Scott-Knott test $(\mathrm{p}<0.05)$.

The disease index (DI) was calculated and a RBD was used to the plants submitted to artificial inoculation in a greenhouse, considering the inoculation dates as blocks. The patterns where present in all dates and the genotypes in only one date. Initially, the data of the patterns were subjected to F-test of analysis of variance and averages differentiated by Tukey's test $(\mathrm{p}<0.05)$. As there was no interaction between pattern and date or block, the means of the genotypes DI were corrected by the block effects and compared with the patterns in an analysis with all dates, using the Student's t-test ( $\mathrm{p}<0.05$ ). All analyzes were performed with the aid of R software in version 3.1.0 (R Core Team 2011) and SAS software in version 9.4 (SAS institute 2008).

\section{RESULTS AND DISCUSSION}

When evaluating the presence of dry broom in the cacao plants under study, it was verified that there was a significant effect of the analyzed genotypes $(\mathrm{p}<0.05)$. In the Scott-Knott test, the genotype distinction formed four resistance groups to witches' broom, with average values of dry broom per plant ranging from none to more than 55 (Table 1 ), suggesting the existence of different resistance levels. The dry broom count per plant has already been established as an appropriate parameter for assessing resistance to witches' broom and has been used frequently (Silva et al. 2010; Yamada et al. 2013).

The measurements of trunk diameter and dry broom behaved as independent characteristics, since they presented a correlation of -0.01 . Theoretically, the correlation between the characteristics had already been reported (Faleiro et al. 2006). However, the edaphoclimatic conditions of the experimental area characterized by the "cacau-cabruca" planting system (Brazil 2014) is considered to have provided different shading patterns, soil depth, spacing between plants and wind exposure, which may have influenced the result. In particular, the genetic effect of different varieties is believed to be the main component of the variation of expression of the trait analyzed. Moreover, the age of the plants (over 30 years) may have led them to stable stem growth.

Most plants had a number of dry brooms 3 to 6 times lower than the most susceptible group, suggesting that there are different resistance levels in this germplasm (Fig. 1).

The analysis of variance of the data obtained for the DI considering only the patterns of resistance (SCA6, CCN51 and Catongo) and different dates of inoculation demonstrates that significant effects $(\mathrm{p}<0.01)$ were only observed among genotypes. No significant effects were observed for the date of inoculation or for their interaction with genotypes (Table 2; Fig. 2). Therefore, the obtained responses reflected the resistance variability of the cacao genotypes and not that of the inoculum.

As expected, the used patterns have been significantly different from each other by the Tukey's test $(\mathrm{p}<0.05)$. The SCA6 clone showed DI of 0.27 , while CCN51 showed 0.51 and the Catongo variety showed 0.95 (Table 3 ). The SCA6 clone was selected in Peru in 1942 and has since been used as a source of resistance to witches' broom in cacao breeding programs (Lopes et al. 2011; Teixeira et al. 2015). In fact, in many progeny tests both in the field and the greenhouse, the clone has shown superior performance for disease resistance, having been used as a pattern of resistance in various studies (Lopes et al. 2011; 
Table 1. Mean values of dry brooms in 96 local variety cacao genotypes over two consecutive years.

\begin{tabular}{|c|c|c|c|c|c|}
\hline Genotype & Dry broom (DB) & Genotype & Dry broom (DB) & Genotype & Dry broom (DB) \\
\hline 4015 & $55.50^{\mathrm{A}}$ & 4181 & $18.50^{c}$ & 4076 & $7.50^{\mathrm{D}}$ \\
\hline 4132 & $55.00^{\mathrm{A}}$ & 4184 & $18.50^{c}$ & 4078 & $7.50^{\mathrm{D}}$ \\
\hline 4119 & $45.00^{B}$ & 4007 & $18.00^{C}$ & 4062 & $7.00^{D}$ \\
\hline 4033 & $40.00^{\mathrm{B}}$ & 4151 & $18.00^{c}$ & 4104 & $7.00^{\mathrm{D}}$ \\
\hline 4163 & $40.00^{B}$ & 4095 & $17.00^{c}$ & 4105 & $6.50^{\mathrm{D}}$ \\
\hline 4186 & $33.50^{c}$ & 4178 & $17.00^{D}$ & 4121 & $6.50^{D}$ \\
\hline 4091 & $32.50^{c}$ & 4125 & $16.00^{\mathrm{D}}$ & 4139 & $6.50^{\mathrm{D}}$ \\
\hline 4187 & $29.50^{c}$ & 4047 & $15.00^{\mathrm{D}}$ & 4064 & $6.00^{\mathrm{D}}$ \\
\hline 4162 & $28.50^{c}$ & 4099 & $15.00^{\mathrm{D}}$ & 4112 & $6.00^{\mathrm{D}}$ \\
\hline 4009 & $27.50^{c}$ & 4141 & $15.00^{\mathrm{D}}$ & 4127 & $5.50^{\mathrm{D}}$ \\
\hline 4063 & $27.50^{c}$ & 4161 & $15.00^{\mathrm{D}}$ & 4060 & $4.50^{D}$ \\
\hline 4185 & $27.50^{c}$ & 4092 & $14.50^{\mathrm{D}}$ & 4083 & $4.50^{D}$ \\
\hline 4042 & $27.00^{c}$ & 4103 & $14.00^{\mathrm{D}}$ & 4096 & $4.50^{D}$ \\
\hline 4056 & $25.50^{c}$ & 4067 & $13.50^{\mathrm{D}}$ & 4107 & $4.50^{D}$ \\
\hline 4140 & $25.50^{c}$ & 4126 & $13.50^{\mathrm{D}}$ & 4135 & $4.50^{D}$ \\
\hline 4043 & $25.00^{c}$ & 4115 & $13.00^{\mathrm{D}}$ & 4137 & $4.50^{\mathrm{D}}$ \\
\hline 4098 & $25.00^{c}$ & 4138 & $13.00^{\mathrm{D}}$ & $4070 B$ & $3.50^{\mathrm{D}}$ \\
\hline 4158 & $25.00^{c}$ & 4179 & $12.00^{\mathrm{D}}$ & 4005 & $3.00^{\mathrm{D}}$ \\
\hline 4180 & $24.00^{c}$ & 4109 & $11.50^{\mathrm{D}}$ & 4035 & $3.00^{\mathrm{D}}$ \\
\hline 4089 & $23.50^{c}$ & 4086 & $11.00^{\mathrm{D}}$ & 4084 & $3.00^{\mathrm{D}}$ \\
\hline 4100 & $23.50^{c}$ & 4110 & $11.00^{\mathrm{D}}$ & 4111 & $3.00^{\mathrm{D}}$ \\
\hline 4152 & $22.50^{c}$ & 4177A & $11.00^{\mathrm{D}}$ & 4057 & $2.50^{\circ}$ \\
\hline 4050 & $22.00^{c}$ & 4075 & $10.00^{\mathrm{D}}$ & 4077 & $2.50^{\mathrm{D}}$ \\
\hline 4177B & $21.50^{c}$ & 4133 & $10.00^{\mathrm{D}}$ & 4085 & $2.50^{\mathrm{D}}$ \\
\hline 4031 & $21.00^{c}$ & 4113 & $9.50^{D}$ & 4001 & $2.00^{\mathrm{D}}$ \\
\hline 4045 & $21.00^{c}$ & 4134 & $9.50^{\mathrm{D}}$ & 4054 & $1.50^{\mathrm{D}}$ \\
\hline 4044 & $20.50^{c}$ & 4183 & $9.50^{D}$ & 4058 & $1.50^{D}$ \\
\hline 4156 & $20.50^{c}$ & 4036 & $9.00^{D}$ & 4065 & $1.50^{\mathrm{D}}$ \\
\hline 4176 & $20.00^{c}$ & 4053 & $9.00^{D}$ & 4114 & $1.50^{D}$ \\
\hline 4090 & $19.50^{c}$ & 4069 & $9.00^{D}$ & 4102 & $1.00^{\mathrm{D}}$ \\
\hline 4153 & $19.00^{c}$ & $4070 \mathrm{~A}$ & $8.00^{\mathrm{D}}$ & 4037 & $0.00^{\mathrm{D}}$ \\
\hline 4094 & $18.50^{c}$ & 4059 & $7.50^{\mathrm{D}}$ & 4101 & $0.0^{\mathrm{D}}$ \\
\hline
\end{tabular}

Means followed by the same letters are in a same group by Scott-Knott test $(p<0.05)$.

Pires et al. 2012; Sena et al. 2014). In turn, the CCN51 clone selected in Ecuador, is the result of a breeding between ICS-95, IMC-67 and Canelus, and has been considered a carrier of a moderate resistance to witches' broom (Campo and Andía 1997; Boza et al. 2014). Finally, the Catongo variety (Theobroma leiocarpa Bernoulli), first found in the mid-1930s in Pirangi, Bahia, is considered an albino mutation of Forastero cacao (Dantas Neto et al. 2005) and is often used as a pattern for susceptibility to witches' broom (Pimenta Neto et al. 2018; Benjamin et al. 2016).

Significant effects for DI between 96 cacao genotypes under study were found $(\mathrm{p}<0.01)$. The same was not verified for the block ( $p>0.01$ ) (Table 4). In the Student's t-test, the genotype distinction formed five groups of resistance to witches' broom, based on the DI (Table 5). The genotypes considered highly resistant were those that had a significantly lower DI than CCN51 and Catongo, resistant were those with a significantly lower DI than just the Catongo, and intermediate those that had DI higher than SCA6 or were not significantly different from none. The genotypes considered susceptible were 


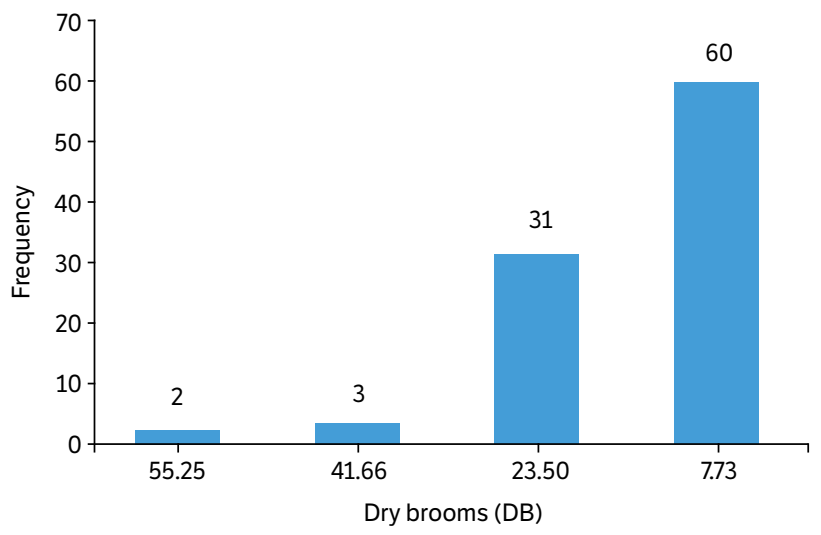

Figure 1. Frequency histogram of 96 local variety cacao genotypes relative to the four witches' broom resistance groups based on the number of dry brooms formed in the Scott-Knott test at $5 \%$ probability.

Table 2. Disease index (DI) analysis of variance on resistance patterns, moderate resistance and susceptibility to witches' broom disease, at different inoculation dates with the fungus Moniliophthora perniciosa.

\begin{tabular}{|c|c|c|c|c|}
\hline Variation sources & DF & Mean SQ & F value & $\operatorname{Pr}(>\mathrm{F})$ \\
\hline Block/Environment & 11 & 0.98 & 0.87 & $0.56^{\mathrm{ns}}$ \\
\hline Genotype & 2 & 75.43 & 68.04 & $<2 \mathrm{e}-16^{\star \star \star}$ \\
\hline Environment: genotype & 22 & 1.46 & 1.30 & $0.16^{\mathrm{ns}}$ \\
\hline Error & 1908 & 1.12 & & \\
\hline Correct Total & 1943 & & & \\
\hline DI Mean & 0.58 & & & \\
\hline $\mathrm{CV}(\%)$ & 29.01 & & & \\
\hline
\end{tabular}

ns: not significant, ${ }^{* * *}$ : significant $\mathrm{p}<0.01$ by the F-test.

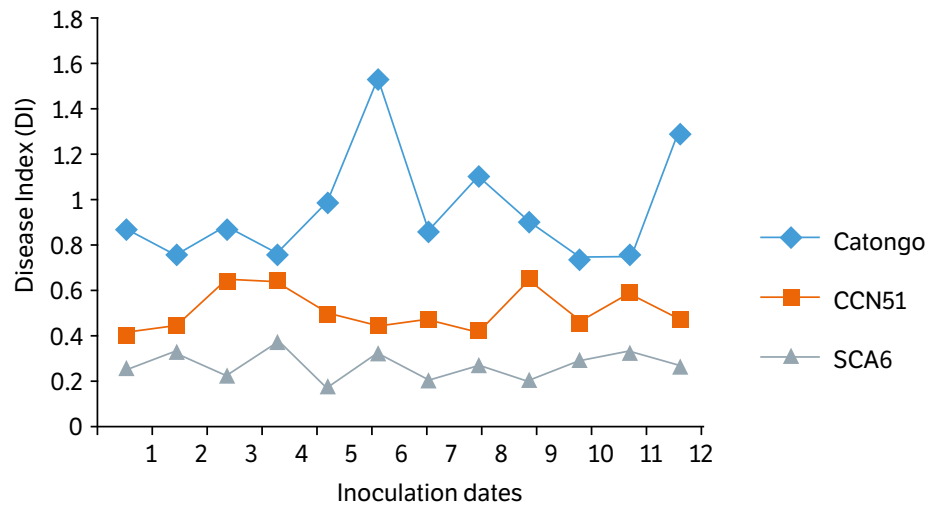

Figure 2. Disease index (DI) of SCA6 and CCN51 clones and Catongo variety in function of different dates of inoculation with the fungus Moniliophthora perniciosa.

those with significantly higher DI than SCA6 and CCN51 and, finally, highly susceptible were those with higher DI than all patterns. The variability of resistance to witches' broom in selected genetic materials on local farms has been reported in important studies (Leal et al. 2008; Lima et al. 2013) and has been reinforced in this paper (Table 5). Numerically considering the value of DI, the distribution of genotypes was mostly more resistant than the Catongo variety and less resistant than the SCA6 clone (Fig. 3).

The susceptibility of local cacao varieties of the cacao region of Bahia has already been reported (Lopes et al. 2011). However, promisingly, the present study found 32 genotypes with averages that are inferior to that of Catongo variety, two of which with averages lower than the SCA6 and CCN51 clones. Unfortunately, the Southern Bahia local cacao germplasm 
Table 3. Mean values of disease index values (DI) of SCA6 and CCN51 clones and Catongo variety.

\begin{tabular}{cl}
\hline Genotype & DI \\
\hline Catongo & $0.95 \pm 1.29^{\mathrm{A}}$ \\
\hline CCN51 & $0.51 \pm 1.05^{\mathrm{B}}$ \\
\hline SCA6 & $0.27 \pm 0.79^{\mathrm{C}}$ \\
\hline
\end{tabular}

Means followed by the same letters are in a same group by Tukey’s test $(p<0.05)$.

Table 4. Disease index (DI) analysis of variance to witches' broom of 96 genotypes of local cacao varieties and 3 resistance patterns at different dates.

\begin{tabular}{|c|c|c|c|c|}
\hline Variation sources & DF & Mean SQ & F value & $\operatorname{Pr}(>\mathrm{F})$ \\
\hline Block/Environment & 11 & 0.98 & 0.71 & $0.73^{\text {ns }}$ \\
\hline Genotypes & 98 & 8.50 & 6.13 & $3.18 \mathrm{e}-06^{\star \star \star}$ \\
\hline Error & 7018 & 1.38 & & \\
\hline Correct Total & 7127 & & & \\
\hline DI Mean & 0.71 & & & \\
\hline CV (\%) & 23.26 & & & \\
\hline
\end{tabular}

ns: not significant, ${ }^{* * \star}$ : significant $\mathrm{p}<0.01$ by the F-test.

suffered losses of up to $90 \%$ in the 1990s, when the disease showed the highest damage to cacao cultivation in the region (Oliveira and Luz 2005). Interestingly, even after 30 years since the first reports of the disease at the field (Pereira et al. 1989), some of these varieties are still present in crops. There are lines of studies that argue that this is due to the random crossing of these plants with resistant clones distributed on farms by the Executive Commission of the Cacao Plant (Centro de Pesquisa da Lavoura Cacaueira - CEPLAC), since the arrival of the disease in the region (Lopes et al. 2011). However, the possibility that there are different sources of Scavina- 6 resistance in the genetic background in question is not ruled out. This is because the gene combination phenomenon from random crossing in cacao cultivation has already been verified (Benjamin et al. 2016). Additionally, it is possible that there is greater genetic diversity of cacao accesses in commercial plantations in Bahia compared to the genotypes corresponding to the alleged parents used to produce hybrid cacao varieties (Leal et al. 2008).

The genotypes 4031 and 4037 showed, with significant difference, DI means lower than the CCN51 and Catongo variety, suggestive to strong resistance to witches' broom. Approximately $34 \%$ of the genotypes showed DI means significantly lower than the Catongo variety and with no statistical difference with the CCN51 and SCA6 clones, also worthy of prominence in the selection for resistance. Approximately $9 \%$ of the genotypes showed DI means that did not differ significantly from any patterns used in the experiment. It is also noteworthy that $25 \%$ of the 96 evaluated genotypes had higher DI means than the SCA6 and CCN51 clones, but without statistical difference with the Catongo variety, being therefore considered susceptible to witches' broom. Finally, approximately $7 \%$ of the genotypes had higher DI means than all the patterns, suggesting a high susceptibility to the mentioned disease (Table 5).

There was a significant $(\mathrm{p}<0.05)$ moderate correlation $(0.31)$ between the variables DI and DB. Although the interpretation of the magnitude of the correlation coefficient depends on specific application context, the found value suggests that the dry broom count per plant is a good predictor for evaluation of resistance level to witches' broom. However, the same per se does not exclude the importance of progeny studies in greenhouses which are conducted in order to prevent escape.

Promisingly, the genotypes 4037, 4057, 4070B, 4078, 4069, 4083, 4059, 4113, 4076, 4101, 4139, 4111, 4134, 4065, 4141, $4138,4103,4058,4084,4121,4127,4102,4005,4137,4054,4060,4047,4099$ showed greater resistance in both greenhouse and field evaluations, while the genotypes 4119 and 4033 were among the most susceptible in both assessments.

According to the morphoagronomic characterization of this population, the genotypes with resistant behavior, 4057, 4070B, 4078, 4069, 4083, 4059, 4076, 4065, 4058, 4084, 4054, 4060, 4099, are classified as cacao comum, while 4113, 4101, 4139, 4111, 
Table 5. Individual comparison among adjusted means values of witches' broom disease index (DI) from 96 genotypes of local cacao varieties versus the SCA6 (resistance pattern) and CCN51 (moderate resistance pattern) clones and Catongo variety (susceptibility pattern) at inoculated with the Moniliophthora perniciosa fungus, and error probability for the difference observed between the means, by the t-test.

\begin{tabular}{|c|c|c|c|c|c|}
\hline \multirow{2}{*}{ Genotype } & \multirow{2}{*}{ DI Mean } & SCA6 & CCN51 & Catongo & \multirow{2}{*}{ Class } \\
\hline & & $X=0.27$ & $X=0.51$ & $X=0.95$ & \\
\hline 4031 & -0.01 & 0.1391 & 0.0064 & $<0.0001$ & $\mathrm{HR}$ \\
\hline 4037 & 0.12 & 0.4119 & 0.0384 & $<0.0001$ & $\mathrm{HR}$ \\
\hline 4057 & 0.14 & 0.4858 & 0.0515 & $<0.0001$ & $\mathrm{R}$ \\
\hline $4070 B$ & 0.14 & 0.4959 & 0.0535 & $<0.0001$ & $\mathrm{R}$ \\
\hline 4078 & 0.15 & 0.5176 & 0.0578 & $<0.0001$ & $\mathrm{R}$ \\
\hline 4069 & 0.16 & 0.5479 & 0.0641 & $<0.0001$ & $\mathrm{R}$ \\
\hline 4083 & 0.25 & 0.9228 & 0.1779 & 0.0002 & $\mathrm{R}$ \\
\hline 4059 & 0.27 & 0.9851 & 0.2044 & 0.0003 & $\mathrm{R}$ \\
\hline 4113 & 0.28 & 0.9725 & 0.2240 & 0.0004 & $\mathrm{R}$ \\
\hline 4076 & 0.28 & 0.9584 & 0.2309 & 0.0004 & $\mathrm{R}$ \\
\hline 4101 & 0.29 & 0.9231 & 0.2485 & 0.0005 & $\mathrm{R}$ \\
\hline 4139 & 0.31 & 0.8623 & 0.2815 & 0.0007 & $\mathrm{R}$ \\
\hline 4111 & 0.31 & 0.8533 & 0.2867 & 0.0007 & $\mathrm{R}$ \\
\hline 4134 & 0.31 & 0.8477 & 0.2899 & 0.0007 & $\mathrm{R}$ \\
\hline 4065 & 0.35 & 0.6729 & 0.4075 & 0.0016 & $\mathrm{R}$ \\
\hline 4141 & 0.37 & 0.6095 & 0.4595 & 0.0021 & $\mathrm{R}$ \\
\hline 4138 & 0.37 & 0.5926 & 0.4744 & 0.0023 & $\mathrm{R}$ \\
\hline 4103 & 0.39 & 0.5222 & 0.5416 & 0.0033 & $\mathrm{R}$ \\
\hline 4058 & 0.42 & 0.4259 & 0.6497 & 0.0053 & $\mathrm{R}$ \\
\hline 4140 & 0.43 & 0.3973 & 0.6863 & 0.0062 & $\mathrm{R}$ \\
\hline 4084 & 0.44 & 0.3840 & 0.7041 & 0.0067 & $\mathrm{R}$ \\
\hline 4121 & 0.44 & 0.3701 & 0.7232 & 0.0072 & $\mathrm{R}$ \\
\hline 4127 & 0.46 & 0.3326 & 0.7784 & 0.0090 & $\mathrm{R}$ \\
\hline 4102 & 0.49 & 0.2603 & 0.9007 & 0.0140 & $\mathrm{R}$ \\
\hline 4007 & 0.51 & 0.2062 & 0.9890 & 0.0204 & $\mathrm{R}$ \\
\hline 4056 & 0.53 & 0.1734 & 0.9116 & 0.0263 & $\mathrm{R}$ \\
\hline 4005 & 0.54 & 0.1637 & 0.8868 & 0.0285 & $\mathrm{R}$ \\
\hline 4137 & 0.54 & 0.1573 & 0.8698 & 0.0301 & $\mathrm{R}$ \\
\hline 4054 & 0.55 & 0.1389 & 0.8185 & 0.0354 & $\mathrm{R}$ \\
\hline 4060 & 0.56 & 0.1232 & 0.7710 & 0.0412 & $\mathrm{R}$ \\
\hline 4047 & 0.57 & 0.1171 & 0.7515 & 0.0438 & $\mathrm{R}$ \\
\hline 4099 & 0.58 & 0.1079 & 0.7209 & 0.0482 & $\mathrm{R}$ \\
\hline 4042 & 0.58 & 0.1024 & 0.7018 & 0.0512 & 1 \\
\hline 4001 & 0.58 & 0.0999 & 0.6929 & 0.0526 & I \\
\hline 4156 & 0.59 & 0.0895 & 0.6544 & 0.0594 & I \\
\hline 4132 & 0.59 & 0.0894 & 0.6540 & 0.0595 & 1 \\
\hline 4089 & 0.59 & 0.0889 & 0.6519 & 0.0599 & 1 \\
\hline 4158 & 0.60 & 0.0850 & 0.6368 & 0.0628 & I \\
\hline 4133 & 0.61 & 0.0766 & 0.6028 & 0.0699 & I \\
\hline 4092 & 0.62 & 0.0642 & 0.5481 & 0.0832 & I \\
\hline
\end{tabular}


Table 5. Continuation.

\begin{tabular}{|c|c|c|c|c|c|}
\hline \multirow{2}{*}{ Genotype } & \multirow{2}{*}{ DI Mean } & SCA6 & CCN51 & Catongo & \multirow{2}{*}{ Class } \\
\hline & & $X=0.27$ & $X=0.51$ & $X=0.95$ & \\
\hline 4162 & 0.63 & 0.0587 & 0.5219 & 0.0906 & I \\
\hline 4009 & 0.64 & 0.0488 & 0.4717 & 0.1067 & 1 \\
\hline 4179 & 0.66 & 0.0418 & 0.4322 & 0.1217 & I \\
\hline 4115 & 0.67 & 0.0334 & 0.3803 & 0.1455 & I \\
\hline 4110 & 0.68 & 0.0310 & 0.3645 & 0.1539 & I \\
\hline 4105 & 0.69 & 0.0277 & 0.3416 & 0.1670 & I \\
\hline 4104 & 0.71 & 0.0220 & 0.2978 & 0.1964 & I \\
\hline 4125 & 0.73 & 0.0162 & 0.2479 & 0.2390 & I \\
\hline 4036 & 0.73 & 0.0147 & 0.2341 & 0.2530 & I \\
\hline 4094 & 0.74 & 0.0136 & 0.2232 & 0.2649 & I \\
\hline 4015 & 0.74 & 0.0125 & 0.2118 & 0.2783 & I \\
\hline 4135 & 0.75 & 0.0108 & 0.1941 & 0.3009 & I \\
\hline 4186 & 0.78 & 0.0075 & 0.1546 & 0.3631 & I \\
\hline 4177B & 0.78 & 0.0072 & 0.1502 & 0.3713 & I \\
\hline 4075 & 0.78 & 0.0071 & 0.1486 & 0.3743 & I \\
\hline 4161 & 0.79 & 0.0066 & 0.1430 & 0.3854 & I \\
\hline 4085 & 0.79 & 0.0063 & 0.1377 & 0.3962 & I \\
\hline 4178 & 0.80 & 0.0055 & 0.1273 & 0.4190 & I \\
\hline 4187 & 0.80 & 0.0054 & 0.1256 & 0.4230 & I \\
\hline 4095 & 0.81 & 0.0040 & 0.1029 & 0.4828 & I \\
\hline 4163 & 0.84 & 0.0029 & 0.0842 & 0.5445 & 1 \\
\hline 4096 & 0.84 & 0.0027 & 0.0809 & 0.5571 & I \\
\hline 4126 & 0.84 & 0.0025 & 0.0757 & 0.5778 & I \\
\hline 4045 & 0.86 & 0.0018 & 0.0620 & 0.6409 & I \\
\hline 4114 & 0.88 & 0.0014 & 0.0512 & 0.7015 & I \\
\hline 4176 & 0.90 & 0.0009 & 0.0372 & 0.8031 & $S$ \\
\hline 4077 & 0.92 & 0.0006 & 0.0298 & 0.8726 & $S$ \\
\hline 4053 & 0.93 & 0.0005 & 0.0273 & 0.8999 & $S$ \\
\hline 4033 & 0.94 & 0.0004 & 0.0233 & 0.9482 & $S$ \\
\hline 4062 & 0.96 & 0.0003 & 0.0181 & 0.9750 & $S$ \\
\hline 4098 & 0.96 & 0.0003 & 0.0159 & 0.9367 & $S$ \\
\hline 4086 & 0.98 & 0.0002 & 0.0131 & 0.8814 & $S$ \\
\hline 4152 & 1.00 & 0.0001 & 0.0090 & 0.7797 & $S$ \\
\hline 4100 & 1.00 & 0.0001 & 0.0087 & 0.7704 & $S$ \\
\hline 4184 & 1.02 & $<0.0001$ & 0.0073 & 0.7274 & $S$ \\
\hline $4070 \mathrm{~A}$ & 1.03 & $<0.0001$ & 0.0056 & 0.6615 & $S$ \\
\hline 4035 & 1.04 & $<0.0001$ & 0.0049 & 0.6293 & $S$ \\
\hline 4151 & 1.04 & $<0.0001$ & 0.0046 & 0.6169 & $\mathrm{~S}$ \\
\hline 4181 & 1.08 & $<0.0001$ & 0.0024 & 0.4820 & $S$ \\
\hline 4064 & 1.09 & $<0.0001$ & 0.0023 & 0.4702 & $\mathrm{~S}$ \\
\hline 4063 & 1.10 & $<0.0001$ & 0.0019 & 0.4369 & $\mathrm{~S}$ \\
\hline 4153 & 1.15 & $<0.0001$ & 0.0007 & 0.2982 & $S$ \\
\hline
\end{tabular}


Table 5. Continuation.

\begin{tabular}{|c|c|c|c|c|c|}
\hline \multirow{2}{*}{ Genotype } & \multirow{2}{*}{ DI Mean } & SCA6 & CCN51 & Catongo & \multirow{2}{*}{ Class } \\
\hline & & $X=0.27$ & $X=0.51$ & $X=0.95$ & \\
\hline 4067 & 1.16 & $<0.0001$ & 0.0006 & 0.2707 & $S$ \\
\hline 4090 & 1.21 & $<0.0001$ & 0.0002 & 0.1610 & $\mathrm{~S}$ \\
\hline 4112 & 1.24 & $<0.0001$ & 0.0001 & 0.1215 & $\mathrm{~S}$ \\
\hline 4043 & 1.25 & $<0.0001$ & $<0.0001$ & 0.1067 & $S$ \\
\hline 4183 & 1.30 & $<0.0001$ & $<0.0001$ & 0.0652 & $S$ \\
\hline 4050 & 1.31 & $<0.0001$ & $<0.0001$ & 0.0540 & $\mathrm{~S}$ \\
\hline 4177A & 1.31 & $<0.0001$ & $<0.0001$ & 0.0534 & $S$ \\
\hline 4109 & 1.36 & $<0.0001$ & $<0.0001$ & 0.0283 & $\mathrm{HS}$ \\
\hline 4119 & 1.37 & $<0.0001$ & $<0.0001$ & 0.0258 & HS \\
\hline 4107 & 1.57 & $<0.0001$ & $<0.0001$ & 0.0011 & HS \\
\hline 4091 & 1.58 & $<0.0001$ & $<0.0001$ & 0.0008 & HS \\
\hline 4185 & 1.65 & $<0.0001$ & $<0.0001$ & 0.0002 & HS \\
\hline 4044 & 1.81 & $<0.0001$ & $<0.0001$ & $<0.0001$ & $\mathrm{HS}$ \\
\hline 4180 & 1.91 & $<0.0001$ & $<0.0001$ & $<0.0001$ & HS \\
\hline SCA6 & 0.27 & . & 0.0003 & $<0.0001$ & $\mathrm{R}$ \\
\hline CCN51 & 0.51 & 0.0003 & . & $<0.0001$ & MR \\
\hline Catongo & 0.95 & $<0.0001$ & $<0.0001$ & . & $S$ \\
\hline
\end{tabular}

HR: highly resistant; R: resistant; I: intermediate; S: Susceptible; HS: highly susceptible; MR: moderate resistant.

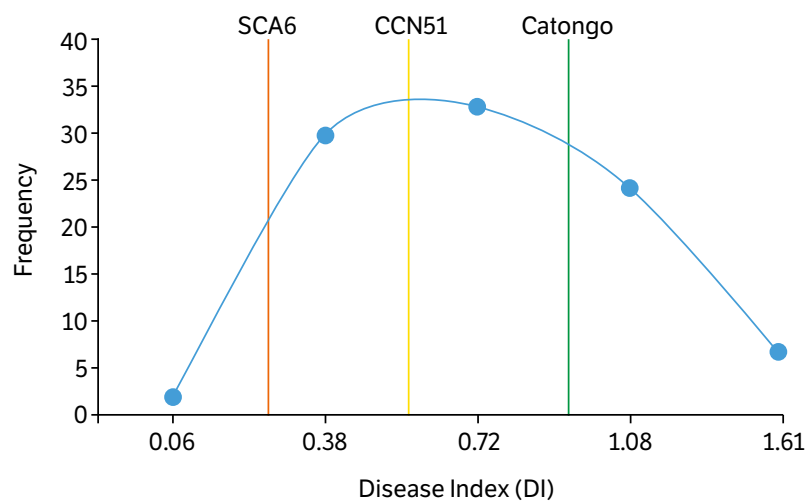

Figure 3. Frequency distribution of 96 local variety cacao genotypes and 3 resistance patterns, relative to the 5 witches' broom resistance groups formed in the disease index (DI) by the t-test.

4134, 4141, 4138, 4103, 4121, 4127, 4102, 4137 are classified as Maranhão and 4005, 4047 and 4037 as Parazinho. On the other hand, among the genotypes with susceptible behavior, 4119 is classified as Maranhão while 4033 as Parazinho. It is interesting to note that approximately $46 \%$ of the genotypes among the most resistant are classified as cacao comum and approximately $43 \%$ as Maranhão. This draws attention to the varieties of cacao comum and Maranhão in the context of resistance to witches' broom.

\section{CONCLUSION}

There are different levels of resistance to witches' broom in the germplasm under study, compatible with the existence in this genetic background of sources of resistance to the disease in question that are possibly different from those traditionally 
used in cacao genetic breeding programs. Therefore, it is essential to continue selection work in local farms and conduct subsequent studies of gene identification with effects on resistance in this population, especially for the 28 genotypes that showed high or moderate resistance.

The report of the occurrence of significant correlation between the two types of tests (field evaluation by counting dry brooms and artificial inoculation in a greenhouse), indicate the effectiveness of both. Thus, the methodology of field evaluation is a good predictor of resistance levels to this disease.

\section{ACKNOWLEDGMENTS}

The authors are grateful to the Executive Committee of the Cacao Crop Plan (CEPLAC) for providing the laboratory and equipment to conduct the fungal research and to the State University of Santa Cruz (UESC); The authors are indebted to the handling editor and the anonymous reviewers for critical reading the manuscript, and to Cláusio Antônio Ferreira de Melo.

\section{FUNDING}

Fundação de Amparo à Pesquisa do Estado da Bahia

Grant No: DTE0035/2013

Conselho Nacional de Desenvolvimento Científico e Tecnológico

Grant No 309841/2015-1

\section{AUTHOR'S CONTRIBUTION}

Conceptualization: Corrêa R. X., Luz E. D. M. N. and Marssaro A. L.; Methodology: Corrêa R. X., Luz E. D. M. N. and Marssaro A. L.; Investigation: Marssaro A. L., Montejo-Diaz A., Montaño-Orellana V. M.; Writting - Original Draft: Massaro A. L.; Writing - Review and Editing: Corrêa R. X.; Resources: Corrêa R. X., Luz E. D. M. N. and Marssaro A. L.; Supervision: Corrêa R. X. and Luz E. D. M. N.

\section{REFERENCES}

[IBGE] Instituto Brasileiro de Geografia e Estatística. (2019). Levantamento sistemático da produção agrícola. [Accessed Nov. $18,2019$. Available at: https://sidra.ibge.gov.br/home/lspa/brasil

Afoakwa, E. O., Paterson, A., Fowler, M. and Ryan, A. (2008). Flavor Formation and Character in Cocoa and Chocolate: A Critical Review. Critical Reviews in Food Science and Nutrition, 48, 840-857. https://doi.org/10.1080/10408390701719272

Benjamin, C. S., Luz, E. D. M. N., Santos, W. O. and Pires, J. L. (2016). Cacao families and parents selected as resistant to natural infection of Moniliophthora perniciosa. Crop Breeding and Applied Biotechnology, 16, 141-146. https://doi.org/10.1590/1984-70332016v16n2a21

Boza, E. J., Motamayor, J. C., Amores, F. M., Cedeño-Amador, S., Tondo, C. L., Livingstone, D. S., Schnell, R. J. and Gutiérrez, O. A. (2014). Genetic characterization of the cacao cultivar CCN 51: Its impact and significance on global cacao improvement and production. Journal of the American Society for Horticultural Science, 139, 219-229. https://doi.org/10.21273/JASHS.139.2.219

Brazil. Ministério da Agricultura, Pecuária e Abastecimento. (2014). Implantação do cacaueiro em sistemas agroflorestais. Brasília: MAPA/ACS. 
Brasil. Ministério da Agricultura, Pecuária e Abastecimento. (2019). Brasil é reconhecido como país exportador de cacau fino e de aroma. Brasília: MAPA. [Accessed Nov. 18, 2019]. Available at: https://www.gov.br/agricultura/pt-br/assuntos/noticias/ brasil-e-reconhecido-como-pais-exportador-de-cacau-fino-e-de-aroma

Campo, E. C. and Andía, F. C. (1997). Cultivo y beneficio del cacao CCN51. Quito: Editorial El Conejo.

Dantas Neto, A., Corrêa, R. X., Monteiro, W. R., Luz, E. D. M. N., Gramacho, K. P. and Lopes, U. V. (2005). Caracterização de uma população de cacaueiro para mapeamento de genes de resistência à vassoura-de-bruxa e podridão-parda. Fitopatologia Brasileira, 30, $380-386$. https://doi.org/10.1590/S0100-41582005000400007

Dickstein, E. R., Purdy, L. H. and Frias, G. A. (1987). Crinipellis perniciosa, the cacao witches' broom fungus: Inoculum production and storage. Phytopathology, 77, 1747.

Faleiro, A. S. G., Faleiro, F. G., Lopes, U. V., Melo, G. R. P., Monteiro, W. R., Yamada, M. M., Bahia, R. C. S. and Corrêa, R. X. (2004). Variability in cacao selected by producers for resistance to witches' broom based on microsatellite markers. Crop Breeding and Applied Biotechnology, 4, 290-297.

Faleiro, F. G., Queiroz, V. T., Lopes, U. V., Guimarães, C. T., Pires, J. L., Yamada, M. M., Araújo, I. S., Pereira, M. G., Schnell, R., Souza Filho, G. A., Ferreira, C. F., Barros, E. G. and Moreira, M. A. (2006). Mapping QTLs for witches' broom (Crinipellis perniciosa) resistance in cacao (Theobroma cacao L.). Euphytica, 149, 227-235. https://doi.org/10.1007/s10681-005-9070-7

Frias, G. A., Purdy, L. H. and Schmidt, R. A. (1995). An inoculation method for evaluating resistance of cacao to Crinipellis perniciosa. Plant Disease, 79, 787-791. https://doi.org/10.1094/PD-79-0787

Leal, J. B., Santos, L. M., Santos, C. A. P., Pires, J. L., Ahnert, D. and Corrêa, R. X. (2008). Diversidade genética entre acessos de cacau de fazendas e de banco de germoplasma na Bahia. Pesquisa Agropecuária Brasileira, 43, 851-858. https://dx.doi.org/10.1590/ S0100-204X2008000700009

Leite, L. R. C. (2018). Estudo de competitividade do cacau e chocolate no Brasil: desafios na produção e comércio global. Brasília: Ministério da Indústria, Comércio Exterior e Serviços. [Accessed Nov. 6, 2019]. Available at: http://www.unesco.org/new/fileadmin/ MULTIMEDIA/FIELD/Brasilia/pdf/brz_sc_cadau_chocolate_MICS_por_2018.pdf

Lima, E. M., Pereira, N. E., Pires, J. L., Barbosa, A. M. M. and Corrêa, R. X. (2013). Genetic molecular diversity, production and resistance to witches' broom in cacao clones. Crop Breeding and Applied Biotechnology, 13, 127-135. https://doi.org/10.1590/S1984-70332013000200005

Lopes, U. V., Monteiro, W. R., Pires, J. L., Clement, D., Yamada, M. M. and Gramacho, K. P. (2011). Cacao breeding in Bahia, Brazil - strategies and results. Crop Breeding and Applied Biotechnology, 11, 73-81. https://doi.org/10.1590/S1984-70332011000500011

Oliveira, M. L. and Luz, E. D. M. N. (2005). Identificação e manejo das principais doenças do cacaueiro no Brasil. Ilhéus: CEPLAC/ CEPEC/SEFIT.

Pereira, J. L., Ram, A., Figueiredo, J. M. and Almeida, L. C. C. (1989). Primeira ocorrência de vassoura-de-bruxa na principal região produtora de cacau do Brasil. Revista Agrotrópica, 1, 79-81.

Pimenta Neto, A. A., Laranjeira, D., Pires, J. L. and Luz, E. D. M. N. (2018). Selection of cocoa progenies for resistance to witches' broom. Tropical Plant Pathology, 43, 381-388. https://doi.org/10.1007/s40858-017-0208-7

Pinto, L. R. M. and Pires, J. L. (1998). Seleção de plantas de cacau resistentes à vassoura-de-bruxa [Boletim técnico 181]. Ilhéus: CEPLAC.

Pires, J. L., Melo, G. P., Yamada, M. M. and Gramacho, K. P. (2012). Association among sources of resistance to witches' broom disease for the increment of the level and durability of the character. Revista Agrotrópica, 24, 27-30.

Ploetz, R. (2016). The impact of diseases on cacao production: a global overview. In B. Bailey and L. Meinhardt (Eds.), Cacao Diseases: A History of Old Enemies and New Encounters (p. 33-59). Cham: Springer. https://doi.org/10.1007/978-3-319-24789-2_2 
R Core Team. (2011). R: A language and environment for statistical computing. Vienna: R Foundation for Statistical Computing. http:// www.R-project.org/

Rodrigues, G. S., Pires, J. L. and Luz, E. D. M. N. (2019). Índice de severidade da vassoura-de-bruxa para avaliar genótipos de cacaueiro inoculados artificialmente. Revista Agrotrópica, 31, 255-258.

Santos, E. S. L., Cerqueira-Silva, C. B. M., Mori, G. M., Ahnert, D., Mello, D. L. N., Pires, J. L., Corrêa, R. X. and Souza, A. P. (2015). Genetic structure and molecular diversity of cacao plants established as local varieties for more than two centuries: the genetic history of cacao plantations in Bahia, Brazil. PloS ONE, 10, e0145276. https://doi.org/10.1371/journal.pone.0145276

SAS Institute Inc. (2008). SAS/STAT ${ }^{\circledR} 9.2$ User’s Guide. Carry: SAS Institute Inc.

Sena, K., Alemanno, L. and Gramacho, K. P. (2014). The infection process of Moniliophthora perniciosa in cacao. Plant Pathology, 63, 1272-1281. https://doi.org/10.1111/ppa.12224

Silva, S. D. V. M., Luz, E. D. M. N., Pires, J. L., Yamada, M. M. and Santos Filho, L. P. (2010). Parent selection for cocoa resistance to witches'broom. Pesquisa Agropecuária Brasileira, 45, 680-685. https://doi.org/10.1590/S0100-204X2010000700007

Teixeira, P. J. P. L., Thomazella, D. P. T. and Pereira, G. A. G. (2015). Time for chocolate: current understanding and new perspectives on cacao witches' broom disease research. PLoS Pathogens, 11, e1005130. https://doi.org/10.1371/journal.ppat.1005130

Yamada, M. M., Pires, J. L., Faleiro, F. G., Lopes, U. V. and Macedo, M. M. (2013). Agronomic performance of 27 cocoa progenies and plant selection based on productivity, self-compatibility and disease resistance. Revista Ceres, 60, 514-518. https://doi.org/10.1590/ S0034-737X2013000400010

In the article Resistance to witches' broom in adult plants and progeny of local varieties of cacao in Southern Bahia with DOI: https://doi.org/10.1590/1678-4499.20200341, published in Bragantia vol.79 no.4 Campinas Oct./Dec. 2020:

In the footline where is read Bragantia, Campinas, v. 79, n. 4, p.421-432, 2020 should be read Bragantia, Campinas, v. 79, n. 4, p.546-557, 2020. 